\title{
COVID-19: emergency remote teaching and university professors' mental health
}

Geórgia Maria Ricardo Félix dos Santos 1

(iD) https://orcid.org/0000-0003-0154-597X

Maria Elaine da Silva 2

(iD) https://orcid.org/0000-0002-8331-2215

Bernardo do Rego Belmonte 3

https://orcid.org/0000-0001-5225-5417

1-3 Faculdade de Comunicação Tecnologia e Turismo de Olinda. Av. Getúlio Vargas, 1360. Bairro Novo. Olinda, PE, Brasil. CEP: 53030-010. E-mail: georgia_felix@hotmail.com

\section{Astract}

Objectives: reflections on the experiences of emergency remote teaching by the faculty of the university and the impacts of these professionals' mental health during the COVID-19 pandemic.

Methods: this is a bibliographic review. The descriptors "Docent", "Mental health", "Covid-19", "Higher Education" were used in Portuguese, English and Spanish. The articles found were selected using the pre-established inclusion and exclusion criteria. The text was organized into two thematic approaches: "Emergency remote teaching and the professors" difficulties / challenges" and "Professors' mental health during the COVID-19 pandemic".

Results: in view of the current educational context, professors faced new demands that had repercussions on their social and work routine, due to the increase in the number of hours, the pace and diversity of work. It was evident that these professionals were affected financially, affectively and motivational aspects.

Conclusions: the pandemic brought a series of feelings and perceptions to the professor with new challenges in his/her teaching. However, it is important to encourage the establishment of reflective processes around physical and mental balance in and outside the educational environment.

Key words COVID-19, University professor, Higher education, Mental health

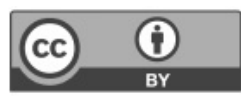




\section{Introduction}

In late December 2019 and early January 2020, China detected a new strain of coronavirus, called SARS-CoV-2 (Severe Acute Respiratory Syndrome of Coronavirus 2), causing COVID-19 (Coronavirus Disease-2019). Faced with the alarming proportion of contagion, little knowledge about the etiological agent and the growing number of deaths at a global level, the World Health Organization (WHO) declared a Public Health Emergency of International Concern. ${ }^{1}$

This epidemiological pandemic scenario caused by the new coronavirus implied the adoption of economic, political, social and sanitary measures at federal, state and municipal levels, which focused on social distancing, reducing the spread of the virus and preventing a collapse in the health system. ${ }^{2}$ Faced with the concern about transmissibility among professors, students and employees, the Higher Education Institutions in Brazil and around the world suspended face-to-face classes and adopted the vast majority - virtual teaching and learning strategies with the objective of trying to reduce the student evasion rate and continue with academic activities, as well as with their teaching calendar. ${ }^{3}$

However, this urgent adherence in remote teaching to meet the chaotic demand of the moment has become another major challenge for the professors. Amidst the adversities imposed by the completely atypical context, marked by fear, uncertainties, doubts and expectations - professors were faced with a real and unequivocal need: to reinvent and innovate their pedagogical strategies while at the same time preserving the quality of teaching. 4

Thus, the new educational reality has demanded momentary and permanent changes in the use of media and Information and Communication Technologies (ICTs) from a critical, reflective, interactive and motivational perspective for students.5,6 Such changes have highlighted even more obstacles and responsibilities of the university in teaching class. ${ }^{7}$

The emergency, complex, compulsory and unstructured migration to remote teaching has led to an increase of hours worked, difficulties in adapting with technological tools, as well as the framing of marital, maternal-family and domestic commitments in the new daily routine. ${ }^{8}$

In addition to a crisis scenario, considered by itself a stressful agent, countless professors have been getting physically and mentally sick in silence, as a consequence of the pressure to achieve the objectives imposed by managers, the blame for the inadequate structure of the teaching institutions and student evasion. 9,10 Researches show the relation between the professors' psychic suffering and emotional instability as a result of the emergency remote teaching which are scarce in scientific literature. Thus, the present study aims to reflect on the experiences of emergency remote teaching by the faculty of the university and the impacts of these professionals' mental health during the COVID-19 pandemic.

\section{Methods}

This is a bibliographic review. For the methodological path, a bibliographic survey of the following terms indexed by the platforms Descritores em Ciências da Saúde (DeCS) (Descriptors in Health Science) and Medical Subject Headings (MeSH) was carried out: "Professor", "Mental Health", "Covid19", "Higher Education" - in Portuguese, English and Spanish, combined with the Boolean operator "AND".

The search for scientific articles in electronic format present in the Cumulative Index to Nursing \& Allied Health Literature (CINAHL), Web of Science Thomson Reuters (Web of Science), as well as in the Google Academic (Google Scholar), the SciELO (Scientific Electronic Library Online) and the Biblioteca Virtual em Saúde (BVS) (Virtual Health Library) databases were carried out in September 2020.

Subsequently, the articles found were selected through the following pre-established inclusion criteria: original articles, review articles, experience reports, reflection articles, editorials written in Portuguese, English and Spanish, available in full and free of charge, published in 2020, related to the COVID-19 pandemic and meeting the research objectives. Duplicate articles, dissertations and theses were excluded.

\section{Results and Discussion}

A total of 203 articles were found in the databases. When applying the exclusion and inclusion criteria, 11 national and international publications were selected, described in Table 1. The analysis of the results was organized in two thematic approaches: "Emergency remote teaching and the professors' difficulties/challenges" and "The professors' mental health during the COVID-19 pandemic". 
Emergency remote teaching and the professors' difficulties / challenges

It is known that the current reality has required undeniable changes in the educational paradigm that are likely to perpetuate itself in the long term, especially in a pandemic context whose end is imprecise. As a prophylactic way of spreading and transmitting the virus, academic classroom activities have been interrupted and the continuity of teaching has been based on the use of ICTs, guided by innovation and flexibility with greater geographical and temporal reach. However, professors were assigned to an important task of virtualizing the educational process in record time. 5,11

Santos study 12 sought to understand the impacts of COVID-19 on online education in Portugal, highlighting communicational, social, technological and pedagogical aspects. Regarding the communicational aspects, the "digital monologues",12 highlighted by the impoverishment of communication, sharing experiences, expressions, feelings, emotions, knowledge and practices between professor and student are highlighted. The absence of interacting and the natural and physical interpersonal relationship, face to face, as well as the action of turning off the camera and audio in videoconferences, consolidates the unidirectional logic of teaching and increases even more the professors' perception of speaking alone.

Paradoxically, as social aspects, the incompatibilities of the home office with personal life are highlighted.12 Thus, social distancing, transfer and adaptation of work at home, as well as the intrusion of technologies in homes, have caused a sense of loss of the professors' private life and family life. Online and offline life have been blended by the veiled expression "being closer to the student" and their daily routines have been totally altered. 13

Regarding the technological aspects, the lack of resources and technophobia stand out. ${ }^{12}$ A study carried out with higher education professors, working in Brazilian public and private institutions, revealed that $91.9 \%$ of the professionals have equipment to teach remote classes. Of this total, only $11.3 \%$ receive financial support from institutions as a way to improve technological support. 14

According to the Higher Education Census, 15 in 2018 , there were a total of 384,474 higher education professors working in the public $(45.2 \%)$ and private (54.8\%) networks in Brazil, the age of 38 being the most frequent among professors. This age group represents professors who were born in the $1980 \mathrm{~s}$, and therefore, followed the implementation of the
Internet in the country. On the other hand, older professors are culturally more resistant to technodigital pedagogical changes, which can influence the ability to understand and use the equipment effectively. 16

Another difficulty faced by professors refers to the pedagogical aspects, in other words, the fragility in developing skills directed at the methodological strategies and teaching practices of online education. ${ }^{12}$ In fact, a study carried out in the prepandemic period already highlighted difficulties in the use of technological tools, digital platforms, and the lack of specific training, ${ }^{17}$ a condition that has been repeated during the new coronavirus pandemic. 18

On the other hand, in a study 14 conducted with higher education professors in the State of Rio de Janeiro, $58.1 \%$ of the interviewees had experience in teaching remote classes, while $29 \%$ did not have the skills to do so. Still according to these authors, $67.7 \%$ of the professionals mentioned having received training and capacity from the institutions to which they were linked to. But $21 \%$ did not receive the proper training.

It is important to emphasize that within the educational and training logic, it is fundamental to make available to professors a workload for planning, organizing the subjects and training. 19 An immediate change in the traditional educational model without proper professor training can have negative effects on the effectiveness, the quality of teaching and the performance of these professionals. 12

The professors' central role is not to use digital resources at random, or apply ready-made technologies, but to fully assume the role of knowledge builder and guide. This implies in organizing and adjusting their classes and subjects to this new online format, according to the students' learning needs, seeking appropriate and personalized didactic alternatives that stimulate participation, inclusion and knowledge assimilation. 20

\section{Professors' mental health during the COVID-19 pandemic}

To better understand the professors' demands, it is necessary to analyze them in the labor and mental health context. Unfortunately, national and global changes in labor legislation, the expansion of private institutions and the decline of stable employment have impacted on the teaching activity. As a consequence, this has generated a precariousness and intensification at work - focused on profit and 
Table 1

\begin{tabular}{|c|c|c|c|c|c|}
\hline Number & Location & Authors & Journals & Title & Type \\
\hline 1 & SCIELO & $\begin{array}{l}\text { Silva AF, Estrela F, Lima } \\
\text { NS, Abreu CTDA }\end{array}$ & Physis & $\begin{array}{l}\text { University Professors' mental } \\
\text { health in times of the pandemic }\end{array}$ & Commentary \\
\hline 2 & SCIELO & $\begin{array}{l}\text { Gemelli CE, Closs LQ, } \\
\text { Fraga AM. }\end{array}$ & $\begin{array}{l}\text { REAd: Rev Eletrôn } \\
\text { Adm. [online] }\end{array}$ & $\begin{array}{l}\text { Multiformity and: } \\
\text { (re)configurations of the } \\
\text { professor's teaching in private } \\
\text { higher education under flexible } \\
\text { capitalism }\end{array}$ & Original Article \\
\hline 3 & $\begin{array}{c}\text { Google } \\
\text { Academic }\end{array}$ & $\begin{array}{l}\text { Barbosa AM, Viegas, } \\
\text { MAS, Batista RLNFF. }\end{array}$ & Rev Augustus & $\begin{array}{l}\text { Face-to-face classes in times of } \\
\text { pandemic: reports on professors' } \\
\text { experiences of Higher Education } \\
\text { in remote classes }\end{array}$ & Original Article \\
\hline 4 & $\begin{array}{c}\text { Google } \\
\text { Academic }\end{array}$ & $\begin{array}{l}\text { Honorato HG, Marcelino } \\
\text { ACKB. }\end{array}$ & $\begin{array}{l}\text { REDE: Diálogos da } \\
\text { Educação }\end{array}$ & $\begin{array}{l}\text { The art of teaching and the } \\
\text { pandemic COVID-19: the } \\
\text { professors' vision }\end{array}$ & Original Article \\
\hline 5 & $\begin{array}{c}\text { Google } \\
\text { Academic }\end{array}$ & $\begin{array}{l}\text { Oliveira ZM, Freitas LMA, } \\
\text { Cantos NCN, Dias JAA, } \\
\text { Freitas MCA, Oliveira TM. }\end{array}$ & $\begin{array}{l}\text { Rev Enf Atual in } \\
\text { Derme }\end{array}$ & $\begin{array}{l}\text { Strategies to return to Higher } \\
\text { Education in Health with COVID- } \\
19\end{array}$ & Reflection Article \\
\hline 6 & SciELo & Silva SMF, Oliveira A F. & Psicol Esc e Educ & $\begin{array}{l}\text { Burnout in university professors' } \\
\text { from private teaching }\end{array}$ & Original Article \\
\hline 7 & $\begin{array}{l}\text { Google } \\
\text { Academic }\end{array}$ & $\begin{array}{l}\text { Expósito CD, Marsollier } \\
\text { RG. }\end{array}$ & $\begin{array}{l}\text { Educación y } \\
\text { Humanismo }\end{array}$ & $\begin{array}{l}\text { Virtualidad y educación em } \\
\text { tiempos de COVID-19. Un e } \\
\text { studio empírico en Argentina }\end{array}$ & Original Article \\
\hline 8 & $\begin{array}{c}\text { Google } \\
\text { Academic }\end{array}$ & $\begin{array}{l}\text { Villafuerte J, Bello J, } \\
\text { Cevallos Y, Bermello J. }\end{array}$ & REFCalE & $\begin{array}{l}\text { Rol de los docentes ante la crisis } \\
\text { del COVID-19, una mirada desde } \\
\text { el enfoque humano }\end{array}$ & Original Article \\
\hline 9 & $\begin{array}{l}\text { Virtual Library } \\
\text { in Health }\end{array}$ & $\begin{array}{l}\text { Araújo FJO, Lima LSA, } \\
\text { Cidade PIM, Nobre CB, } \\
\text { Rolim Neto ML. }\end{array}$ & Psychiatry Res & $\begin{array}{l}\text { Impact of Sars-Cov-2 and its } \\
\text { Reverberation in Global Higher } \\
\text { Education and Mental Health }\end{array}$ & Letter to Editor \\
\hline 10 & $\begin{array}{l}\text { Virtual Library } \\
\text { in Health }\end{array}$ & Wang J, Wang Z. & $\begin{array}{l}\text { Int J Environ Res } \\
\text { Public Health }\end{array}$ & $\begin{array}{l}\text { Strengths, Weaknesses, } \\
\text { Opportunities and Threats } \\
\text { (SWOT) Analysis of China's } \\
\text { Prevention and Control Strategy } \\
\text { for the COVID-19 Epidemic }\end{array}$ & Review Article \\
\hline 11 & $\begin{array}{l}\text { Virtual Library } \\
\text { in Health }\end{array}$ & $\begin{array}{l}\text { Torales J, O'Higgins M, } \\
\text { Castaldelli- Maia JM, } \\
\text { Ventriglio A. }\end{array}$ & Int J Soc Psychiatry & $\begin{array}{l}\text { The outbreak of COVID-19 } \\
\text { coronavirus and its impact on } \\
\text { global mental health }\end{array}$ & Review Article \\
\hline
\end{tabular}


productivity. In this scenario, the professor has become a seasonal service provider, easily replaced, who must meet goals, be flexible and accept the multiplicity of tasks and pressures, physically and mentally to remain employed. 21

A study conducted in 2019 found that the average weekly teaching workload was 32.5 hours. Of the total number of interviewees, $48.3 \%$ confirmed a workload of 40 hours per week, with confirmations of workloads exceeding 45 hours per week. ${ }^{9}$ It is important to point out that the emergency remote teaching established by the pandemic has demonstrated an extraordinary capacity of professors to perform their work in a $24 / 7-(24$ hours and 7 days) per week. ${ }^{22}$ That is, a continuous routine, without breaks, with absolute and unrestricted availability that goes beyond the contractual workload with the objective of clearing students' doubts.

This permanent commitment, many times during the three shifts, is also extended to other activities inherent to teaching, such as: planning activities, preparation and recording of video-classes, reading of texts, orientation of works, reception and correction of exercises performed by students, completion of time of presence and spreadsheet of students' grades, administrative and bureaucratic work, links at different institutions, completion of specializations and improvement courses, participation in events and extension projects, publications of scientific materials, and among others. ${ }^{23}$

In addition, during the pandemic, the professor has played roles far beyond pedagogical ones, needing to learn about information and communication technologies (ICTs) by him/herself and transform his/her home into a real recording studio. The professor has been an important motivator, academic guide and spiritual advisor to the students, helping them to contain affection and practice resilience. 24,25

Due to the complexity of their multitasking, teaching is among the most stressful work activities. ${ }^{23}$ Studies have shown that the probability of professors developing stress, depression, and anxiety is twice as high when compared to other professions.23,25,26 In Brazil, these professionals rank second in the category of occupational diseases. ${ }^{26}$ According to Moreira and Rodrigues, 27 some disorders and illnesses associated with labor situation expose direct determinations coming from the new structures and constitutions of the work world. In this process, the literature that deals with the relation between work environment and the impacts on mental health states that the conjuncture of exploitation and fragilities of labor conditions bring damage to the professors' health and education workers, 10 evidencing the illness expressed by the professional exhaustion syndrome (Burnout Syndrome). ${ }^{28}$ In China, several professors became mentally ill due to the Covid-19 pandemic, presenting mild depressive disorder, bipolar affective disorder, generalized anxiety, adaptation disorder and Burnout Syndrome. 29

A study conducted in Portugal 12 showed that remote classes are difficult and negative experiences, revealing professors' exhaustion and demotivation to teach in a remote environment. The perception of this condition among professors in Brazil18 was verified through a word cloud, being translated by terms such as: anxiety, panic, tiredness, challenge, exhaustion, uncertainty, insecurity, fear and work overload.

The current context shows that university professors are inserted in an environment favorable to mental illness by the impacts of COVID-19. This illness is related to the journalistic news of morbimortality, concomitant to the pressure coming from Higher Education Institutions regarding the use of digital technologies, linked to personal life and to the stress load of the pandemic itself, which has repercussions on the fear of death. 11,30

Faced with national and world scientific evidence and the scarcity of perception of the professor's mental health, it is necessary for Higher Education Institutions to broaden the professor's biopsychosocial view. It is essential that, even with this whirlwind of feelings present in the COVID-19 pandemic, there are strategies to reduce the professors' intellectual, physical and social overload, as well as locations where they can share their anxieties, fears and other feelings.

\section{Final considerations}

A new educational normality is not improvised. In an exceptional situation, migration to emergency remote education must also encompass institutional and governmental responsibilities and reorganizations through actions involving planning and training. However, the health imperative of COVID19 has shown that the virtualization of teaching has been led by professors, regardless of their difficulties, uncertainties, fear, anxiety, depression and workload. Under the nickname of immobility, this professional category has transformed and resigned its practice with creativity, commitment and responsibility.

The new educational demands, measured by the contemporary capitalist system, have evidenced the 
precariousness of the teaching activity and the increase of the involuntary online workload with the professor being connected and involved with his/her activities for a much longer period of time and without foreseen remuneration. This business model of teaching, characteristic of private higher education organizations, impacts not only on the professors' financial, affective and ethical dimensions, but also on the motivational dimensions, leading to discouragement, depression, anxiety and exhaustion. Furthermore, there should be greater concern and reflection on the professors' challenges and difficul- ties experimenting emergency remote teaching since it requires physical, mental and economical balance.

\section{Authors' contributions}

Santos GMRF, Silva ME and Belmonte BR participated in the conception of the study, selection of the articles, interpretation and discussion of the data, writing, review and the approval of the final version.

\section{References}

1. OPAS/OMS. Organização Pan-Americana da Saúde/ Organização Mundial da Saúde. Folha informativa COVID-19. 2020. [acesso 20 set 2020]. Disponível em: https://www.paho.org/pt/covid19.

2. Pereira MD, De Oliveira LC, Costa CFT, De Oliveira Bezerra CM, Pereira MD, Dos Santos CKA, Dantas EHM A pandemia de COVID-19, o isolamento social, consequências na saúde mental e estratégias de enfrentamento: uma revisão integrativa. Res Society Dev. 2020; 9 (7): 1-35.

3. Arruda EP. Educação remota emergencial: elementos para políticas públicas na educação brasileira em tempos de Covid-19. Em Rede. 2020; 7 (1): 257-75.

4. McKimm J, Gibbs T, Bishop J, Jones P. Health Professions' Educators' Adaptation to Rapidly Changing Circumstances: The Ottawa 2020 Conference Experience. Med Ed Publish. 2020; 9 (1): 1-8.

5. Moreno-Correa SM. La innovación educativa em los tempos del Coronavirus. Salutem Scientia Spiritus. 2020; 6 (1): $14-26$

6. Machado PLP. Educação em tempos de pandemia: O ensinar através de tecnologias e mídias digitais. Rev Cient Multidisciplinar Núcleo Conhecimento. 2020; 08: 58-68.

7. Bosi AP. A precarização do trabalho docente nas Instituições de Ensino Superior do Brasil nesses últimos 25 anos. Educ Soc. 2007; 28 (101): 1503-23.

8. Losekann RGCB, Mourão HC. Desafios do teletrabalho na pandemia Covid -19: quando o home vira office. Cad Adm. Maringá. 2020; 28 (Ed. Esp): 71-5. Disponível em: http://periodicos.uem.br/ojs/index.php/CadAdm/article/vie w/53637/751375150139

9. Sanchez HM, Sanchez EGDM, Barbosa MA, Guimarães EC, Porto CC. Impacto da saúde na qualidade de vida e trabalho de docentes universitários de diferentes áreas de conhecimento. Ciênc Saúde Coletiva. 2019; 24 (11): 4111 22.

10. Silva AF, Estrela F, Lima NS, Abreu CTDA. Saúde mental de docentes universitários em tempos de pandemia. Physis. 2020; 30 (2): 1-4.
11. Oliveira ZM, Freitas LMA, Cantos NCN, Dias JAA, Freitas MCA, Oliveira TM. Estratégias para retomada do ensino superior em saúde frente a COVID-19. Rev Enf Atual in Derme. 2020; 93: 1-21.

12. Santos HMR. Os desafios de educar através da Zoom em contexto de pandemia: investigando as experiencias e perspectivas dos docentes portugueses. Prax Educ. 2020; 15: 1-17.

13. Saraiva K, TraversinI C, Lockmannk A. Educação em tempos de COVID-19: ensino remoto e exaustão docente. Prax Educ. 2020; 15: 1-24.

14. Barbosa AM, Viegas, MAS, Batista RLNFF. Aulas presenciais em tempos de pandemia: relatos de experiencias de professores do nível superior sobre as aulas remotas. Rev Augustus. 2020; 25 (51): 1-17.

15. INEP. Instituto Nacional de Estudos e Pesquisas Educacionais Anísio Teixeira (Inep). Ministério da Educação. Censo de Educação Superior: Notas estatísticas. [acesso em 22 set 2020]. Disponível em: http://download.inep.gov.br/educacao_superior/censo_supe rior/documentos/2019/censo_da_educacao_superior_2018notas_estatisticas.pdf.

16. Machado A, Leite C, Monteiro A. As tecnologias digitais na literatura académica da educação de adultos. LaPlage em Revista. 2019; 5 (2): 86-102.

17. Flores ADM, Ribeiro LM, Echeverria EL. A tecnologia da informação e comunicação no ensino superior: Um olhar sobre a prática docente. Spacios. 2017; 38 (5): 1-14.

18. Honorato HG, Marcelino ACKB. A arte de ensinar e a pandemia COVID-19: a visão dos professores. REDE: Diálogos da Educação. 2020; 1 (1): 208-20.

19. Fortes MAS, Araújo OHA, Araújo MEA, Ribeiro LTF. Planejamento na prática dos professores: entre a formação e as experiências vividas. Rev Intern Form Prof. 2018; 3 (2): 315-24.

20. Dias E, Pinto FCF. A Educação e a Covid-19. Ensaio: Avaliação e Políticas Públicas em Educação [editorial]. Ensaio: Aval Pol Pública Educ. 2020; 28 (108): 545-54. 
21. Gemelli CE, Closs LQ, Fraga AM. Multiformidade e pejotização: (re)configurações do trabalho docente no ensino superior privado sob o capitalismo flexível. REAd: Rev Eletrôn Adm. 2020; 26 (2): 409-38.

22. Crary J, Toledo Junior J. 24/7: capitalismo tardio e os fins do sono. 1 ed. São Paulo: Ubu; 2016.

23. Silva SMF, Oliveira A F. Burnout em professores universitários do ensino particular. Psicol Esc Educ. 2020; 23: 110 .

24. Expósito CD, Marsollier RG. Virtualidad y educación en tiempos de COVID-19. Un e studio empírico en Argentina. Educ Hum. 2020; 22 (39): 1-22.

25. Villafuerte J, Bello J, Cevallos Y, Bermello J. Rol de los docentes ante la crisis del COVID-19, una mirada desde el enfoque humano. REFCalE. 2020; 8 (1): 134-50.

26. Baptista MN, Soares TFP, Raad AJ, Santos LM. Burnout, estresse, depressão e suporte laboral em professores universitários. RPOT. 2019; 19 (1): 564-70.
27. Moreira DZ, Rodrigues MB. Saúde mental e trabalho docente. Estud Psicol. 2018; 23 (3): 236-47.

28. Araújo FJO, Lima LSA, Cidade PIM, Nobre CB, Rolim Neto ML. Impact of Sars-Cov-2 and its Reverberation in Global Higher Education and Mental Health. Psychiatry Res. 2020; 288: 1-2.

29. Wang J, Wang Z. Strengths, Weaknesses, Opportunities and Threats (SWOT) Analysis of China's Prevention and Control Strategy for the COVID-19 Epidemic. Int J Environ Res Public Health. 2020; 17 (7): 1-17.

30. Torales J, O'Higgins M, Castaldelli- Maia JM, Ventriglio A. The outbreak of COVID-19 coronavirus and its impact on global mental health. Int J Soc Psychiatry. 2020; 66 (4): 317-320.

Received on October 5, 2020

Approved on December 7, 2020 